\title{
PENGARUH MEDIA PEMBELAJARAN VIDIO POWERPOINT TERHADAP PENINGKATAN HASIL BELAJAR BIOLOGI PADA KONDISI PANDEMI COVID-19
}

\author{
KUSMIYATI \\ MAN 2 Banjarnegara Jawa Tengah \\ kusmiyati199303@gmail.com
}

\begin{abstract}
ABSTRAK
Dimasa pandemi Covid-19 dimana terjadi peningkatan jumlah kasus penyakit yang meluas di Indonesia, berdampak pada dunia pendidikan yang mengharuskan siswa belajar di rumah melalui pembelajaran jarak jauh (daring). Kendala yang dihadapi siswa pada saat pembelajaaran daring antara lain tidak bisa dengan cepat memahami materi pembelajaran seperti pembelajaran tatap muka. Penelitian ini bertujuan untuk mengetahui efektifitas penggunaan media vidio powerpoint terhadap peningkatan hasil belajar Biologi melalui pembelajaran daring terhadap siswa MAN 2 Banjarnegara kelas XII IPA-1 dimasa pandemi Covid-19. Penelitian ini bersifat kualititatif dan kuantitatif dengan teknik pengumpulan data melalui angket, soal dan diskusi melalui WhatsApp Group yang dilakukan pada 44 siswa kelas XII IPA-1 MAN 2 Banjarnegara tahun pelajaran 2020/2021, dengan metode penelitian tindakan bidang pendidikan model Kemmis. Hasil penelitian terdapat $70,45 \%$ (31 siswa) yang menyatakan kesulitan belajar tanpa media, $0 \%$ menyatakan mudah dan 29,54\% (13 siswa) menyatakan sedang. Hasil nilai ulangan harian menunjukkan hasil ketuntasan dengan KKM 77 pada KD-1 88,63\% (39 siswa) tuntas dan 21,37\% (9 siswa) tidak tuntas, ulangan harian ke dua untuk KD-2 dengan KKM 70 diperoleh data 65,90\% (29 siswa) tuntas dan 34,09\% (15 siswa) tidak tuntas. Hasil penelitian menunjukkan bahwa media pembelajaran vidio powerpoint dapat meningkatkan hasil belajar Biologi pada siswa kelas XII IPA-1 MAN 2 Banjarnegara di masa pandemi Covid-19.
\end{abstract}

Kata Kunci : Vidio Powerpoint, Peningkatan Hasil Belajar

\section{PENDAHULUAN}

Pada akhir tahun pelajaran 2019/2020 dan awal tahun pelajaran 2020/2021 dimana Indonesia sedang dihadapkan dengan fenomena kesehatan yaitu corona virus atau COVID-19, mempengaruhi pemerintah dalam mengambil kebijakan terkait dengan dunia pendidikan yaitu pembelajaran jarak jauh (daring). Oleh karena itu, segala kegiatan seperti kegiatan belajar mengajar (KBM) di Madrasah harus dilakukan di rumah atau dilakukan secara online untuk mencegah penyebaran Covid-19. Ketika pembelajaran secara on line tentunya pada diri siswa muncul banyak kendala. Kendala ini berasal dari dalam (faktor internal) maupun dari luar (faktor eksternal). Kendala faktor internal yang dialami siswa dan sangat menentukan keberhasilan pembelajaran adalah munculnyaa rasa malas dan menunda-nunda dalam belajar ataupun menyelesaikan tugas karena tidak terpantau secara langsung oleh pendidik, juga keinginan bermain atau membuka hal-hal lain yang tidak terkait dengan materi pembelajaran pada saat daring. Factor internal yang lain adalah merasa kesulitan 
apabila materi pembelajaran yang disampaikan pendidik hanya melalui materi kontek tanpa ada penjelasan terhadap materi tersebut, serta tidak adanya hubungan emosional antara pendidik dan siswa seperti pada pembelajaran tatap muka berdampak pada respon belajar siswa yang rendah. Sedangkan faktor eksternal yang mempengaruhi adalah kemampuan finansial dalam membeli paket data, memori HP yang kurang memadai, sulitnya akses sinyal internal, pengaruh lingkungan keluarga yang kurang memotivasi untuk siswa belajar mandiri ataupun kesulitan orang tua/keluarga dalam memotivasi anaknya untuk belajar maupun menyelesaikan tugas pada waktu yang ditentukan oleh pendidik, serta lingkungan di sekitar lingkungan rumah yang tidak mendukung untuk belajar terutama pada saat pembelajaran karena adanya aktivitas yang mempengaruhi konsentrasi belajar siswa. Berdasar hal tersebut menyebabkan peneliti selaku pendidik pada mata pelajaran Biologi membuat media pembelajaran yang sederhana dan siswa dapat mengakses dengan mudah melalui WhatsApp group kelas yaitu berupa media pembelajaran Video Powerpoint dengan durasi maksimal 15 menit.

Media pembelajaran adalah suatu alat bantu yang digunakan untuk menunjang keberhasilan suatu pembelajaran. Menurut Kemp and Dylon, 1985 media pembelajaran mempunyai manfaat dalam: penyampainan pesan pembelajaran menjadi lebih terstruktur, proses pembelajaran menjadi lebih menarik dan lebih interaktif serta dapat berlangsung kapanpun dan dimanapun, waktu pelaksanaan pembelajaran dapat diperpendek, kualitas dapat ditingkatkan, sikap positif siswa dapat ditingkatkan, peran guru berubah kearah yang lebih positif. Secara umum manfaat media pembelajaan antara lain: pesan dalam materi pembelajaran menjadi lebih jelas, waktu dan tenaga tidak terlalu banyak, motivasi belajar meningkat, terjadi interaksi secara langsung antara siswa dengan sumber belajar, siswa dapat belajar secara mandiri, dan memberi rangsangan yang sama pada siswa sehingga diharapkan antar siswa dapat memilki persepsi yang sama (Rudi Susilana, 5-9).

Rekaman gambar yang dapat bergerak dan disertai suara berdasar Kamus Besar Bahasa Indonesia (2006) disebut dengan video. Video ini termasuk dalam katagori bahan ajar audiovisual (pandang dengar) yaitu bahan ajar yang mengkombinasikan antara materi visual yang memberikan sinyal ke indra penglihatan dan materi auditif yang merangsang indra pendengaran. Dengan kombinasi dua indra ini kemampuan siswa dalam merekam materi pembelajaran akan lebih baik, seperti ungkapan yang disampaikan oleh Confucius (filosof cina), "Apa yang saya dengar, saya lupa. Apa yang saya lihat, saya ingat. Apa yang saya lakukan, saya paham". Demikian juga peneliti Mell Silberan menyimpulkan hasil penelitiannya bahwa dengan menambahkan visual pada pembelajaran dapat menaikkan ingatan dari $14 \%$ menjadi $38 \%$, menaikkan $200 \%$ kosa kata dan terjadi pengurangan waktu penympaian materi sampai $40 \%$. Andi Prastowo, (300-302) menyimpulkan manfaat program video dalam pembelajaran dapat memberikan pengalaman yang tidak terduga kepada siswa disebabkan siswa dapat melihat bahan ajar yang tadinya tidak mungkin bisa dilihat, apabila bahan ajar tersebut dikombinasikan dengan animasi dan pengaturan kecepatan, sehingga dapat mendemonstrasikan perubahan suatu hal dari waktu ke waktu, pendidk juga dapat menampilkan presentasi studi kasus tentang kehidupan sebenarnya yang dapat memicu diskusi peserta didik. 
Microsoft powerpoint adalah salah satu bagian program aplikasi yang berfungsi untuk membuat tampilan presentasi (Tim Kompulab, 98). Microsoft powerpoint umumnya digunakan untuk keperluan presentasi dengan menggunakan slide/template. Dimana power point berfungsi sebagai sarana mempermudah presentasi sehingga presentasi berlangsung memuaskan. Untuk menunjang kesuksesan presentasi diperlukan lembar atau slide presentasi yang didesain menarik sehingga siswa akan lebh fokus dan termotivaasi (Duwi Priyatno, 108)

Penelitian ini bertujuan untuk mengetahui efektifitas penggunaan media vidio powerpoint terhadap peningkatan hasil belajar Biologi melalui pembelajaran daring terhadap siswa MAN 2 Banjarnegara kelas XII IPA-1 dimasa pandemi Covid-19. Suatu hal dikatakan hasil belajar apabila: pembelajar (siswa) menyadari proses pembelajaran sehingga timbul motivasi untuk memiliki pengetahuan yang diharapkan, dalam memperoleh pengetahuan terjadi secara bertahap, dan adanya interaksi yang sifatnya manusiawi., terjadi komunikasi dua arah antara siswa dan pendidik karena seorang siswa lebih cepat memiliki pengetahuan karena bantuan pendidik. (Rudi Susilana, 1-2)

Dalam menentukan hasil belajar siswa, pendidik harus merumuskan sejumlah indikator sebagai acuan penilaian dan madrasah juga harus menentukan ketuntasan belajar minimal atau kriteria ketuntasan minimal (KKM) untuk memutuskan seorang siswa sudah tuntas atau belum dalam mengikuti pembelajaran. Dalam merumuskan KKM harus mempertimbangkan 3 hal, yaitu: 1). Kompleksitas materi/kompetensi dimana semakin kompleks materi pembelajan maka nilai KKM semakin rendah. 2). Intake (kualitas siswa) semakin tinggi intake siswa semakin tingai nilai KKM nya. Intake ini dapat diproleh dari rata-rata nilai raport ataupun dari hasil pretest. 3). Daya dukung pembelajaran yaitu pendidik dan sarana prasarana pendidikan, factor daya dukung mempengaruhi nilai KKM suatu kompetensi dasar, semakin tinggi nilai daya dukung semakin tinggi nilai KKM kompetensi dasar tersebut. Pada penilaian dengan menggunakan acuan kriteria, penilaian ini membandingkan capaian siswa dengan kriteria kompetensi yang ditetapkan, tidak membandingkan dengan hasil peserta didik lainnya. Penilaian hasil belajar oleh pendidik merupakan proses pengumpulan atau pengolahan informasi/data tentang capaian pembelajaran siswa untuk mengukur pencapaian hasil belajarnya baik dalam aspek afektif, kognitif dan psikomotor yang dilakukan secara terencana dan sistematis. Penilaian hasil belajar oleh pendidik dilaksanakan untuk memenuhi fungsi formatif dan sumatif dalam bentuk penilaian harian, penilaian tengah semester, penilaian akhir semester, dan penilaian akhir tahun. Penilaian harian dapat berupa ulangan, pengamatan, penugasan, dan/atau bentuk lain yang diperlukan untuk: mengukur dan mengetahui pencapaian kompetensi siswa, menetapkan program remedial atau pengayaan berdasarkan tingkat penguasaan kompetensi, memperbaiki proses pembelajaran, dan menyusun laporan kemajuan hasil belajar. Pada proses penilaian dilakukan dengan memperhatikan 3 pendekatan penlaian yaitu penilaian atas pembelajaran (assessment of learning), penilaian untuk pembelajaran (assessment for learning), dan penilaian sebagai pembelajaran (assessment as learning). Assessment of learning dilakukan untuk mengukur capaian siswa terhadap kompetensi yang telah ditetapkan. Penilaian assessment for learning memungkinkan guru menggunakan informasi kondisi siswa untuk memperbaiki 
pembelajaran, sedangkan assessment as learning memungkinkan siswa melihat capaian dan kemajuan belajarnya untuk menentukan target belajar. (Direktorat Pembinaan SMA Ditjen Pendidikan Dasar dan Menengah, 4-8, 13)

Untuk mengukur kemampuan siswa dalam memahami materi pembelajaran pendidik perlu melakukan proes penilaian yang dapat dilakukan secara lisan, tertulis maupun melalui penugasan. Teknik dengan soal dan jawaban disajikan secara tertulis digunakan untuk mengukur atau memperoleh informasi tentang kemampuan kognitif peserta didik, baik kemampuan pengetahuan (C1), pemahaman (C2), aplikasi (C3), analisis (C4), sintesis (C5), dan evaluasi (C6). Tes tertulis ini menuntut tanggapan dari siswa sehingga siswa tersebut dapat diketahui perkembangan kognitif yang diperolehnya. Pada tes tertulis instrumen yang digunakan dapat dalam bentuk soal objektif, essay, jawaban singkat, pernyataan benar salah maupun soal menjodohkan. Sedangkan instrument tes lisan menggunakan kuis dan tanya jawab. Tes lisan dapat digunakan untuk mengukur kemampuan siswa mengolah informasi dan mengkomunikasikan. Instrument penugasan dengan pola pemberian tugas secara individu atau kelompok, dilakukan setelah pembelajaran (assessment of learning) dan sebelum atau dalam proses pembelajaran (assessment for learning), dengan penekanan pada penyelesaian problem solving dan menghasilkan produk. Teknik penugasan ini dapat digunakan untuk mengukur kemampuan afektif maupun psikomotor dari siswa. Pemberian tugas yang diberikan kepada siswa harus: menyesuikan dengan pencapaian indikator hasil belajar, dapat dikerjakan oleh siswa selama proses pembelajaran atau merupakan bagian dari pembelajaran mandiri, disesuaikan dengan taraf perkembangan siswa, materi didasarkan pada kurikulum, pada tugas kelompok rincian tugas setiap anggota kelompok harus dijelaskan, kualitas hasil tugas yang diharapkan disampaikan secara jelas, dan harus mencantumkan rentang waktu pengerjaan tugas (Direktorat Pembinaan SMA Ditjen Pendidikan Dasar dan Menengah, 24,30-31)

Dari hasil penelitian menunjukkan penggunaan media pembelajaran video powerpoint lebih efektif dalam proses pembelajaran karena menyertakan materi pembelajaran pada powerpoint dan siswa dapat mendengarkan penjelasan. Dari hasil penelitian ini peneliti berharap pemanfaatan media pembelajaran Video Powerpoint dapat menjadi alternative media pembelajaran pada saat pembelajaran jarak jauh maupun pembelajaran di luar jaringan.

\section{METODOLOGI PENELITIAN}

Penelitian ini bersifat kualititatif dan kuantitatif dengan teknik pengumpulan data observasi melalui angket, soal dan wawancara dengan media WhatsApp. Dengan subjek penelitian adalah Siswa Kelas XII IPA-1 MAN 2 Banjarnegara Jawa Tengah Tahun Pelajaran 2020/2021 yang berjumlah 44 siswa. Rancangan penelitian dilakukan melalui beberapa tahap yaitu: menyusun angket penelitian, membagikan angket penelitian secara online melalui WhatsApp, mengumpulkan angket penelitain, mengolah dan menganalisa angket, melakukan pembelajaran daring KD-1 materi pembelajaran pertumbuhan dan perkembangan tumbuhan dengan menggunakan media pembelajaran video powerpoint, melakukan pembelajaran daring materi pembelajaran KD-2 metabolism dengan menggunakan media pembelajaran video powerpoint, melakukan ulangan harian, mengumpulkan data hasil ulangan harian, menganalisa data 
hasil ulangan harian, memberikan tugas setiap pembelajaran, melakukaan diskusi melalui WhatsApp untuk mendapatkan data secara langsung. Penelitian dilakukan mulai selasa, 13 Juli 2020 s.d. Jumat, 25 September 2020 di MAN 2 Banjarnegara. Analisis data hasil penelitian terdiri dari analisa hasil angket, penilaian belajar, dan penilaian tugas. Instrument analisis angket penelitian siswa untuk mengukur tingkat kesulitan belajar siswa, instrumen analisis hasil penilaian belajar untuk mengukur hasil belajar ranah pengetahuan dengan menggunakan soal pilihan ganda 25 soal dengan opsion 5 pilihan yaitu A-B-C-D-E materi pembelajaran pertumbuhan dan perkembangan tumbuhan dan 25 soal untuk materi mtabolisme. Soal penilaian hasil belajar untuk mengetahui nilai pengetahuan siswa MAN 2 Banjarnegara dengan ketuntasan individu 77 (KKM) untuk materi pertumbuhan dan perkembangan tumbuhan dan 70 (KKM) untuk materi metabolisme. Instrument analisis hasil penilaian penugasan untuk mengukur tingkat kedisiplinan siswa dengan indikator ketepatan waktu mengumpulkan.

\section{HASIL PENELITIAN DAN PEMBAHASAN}

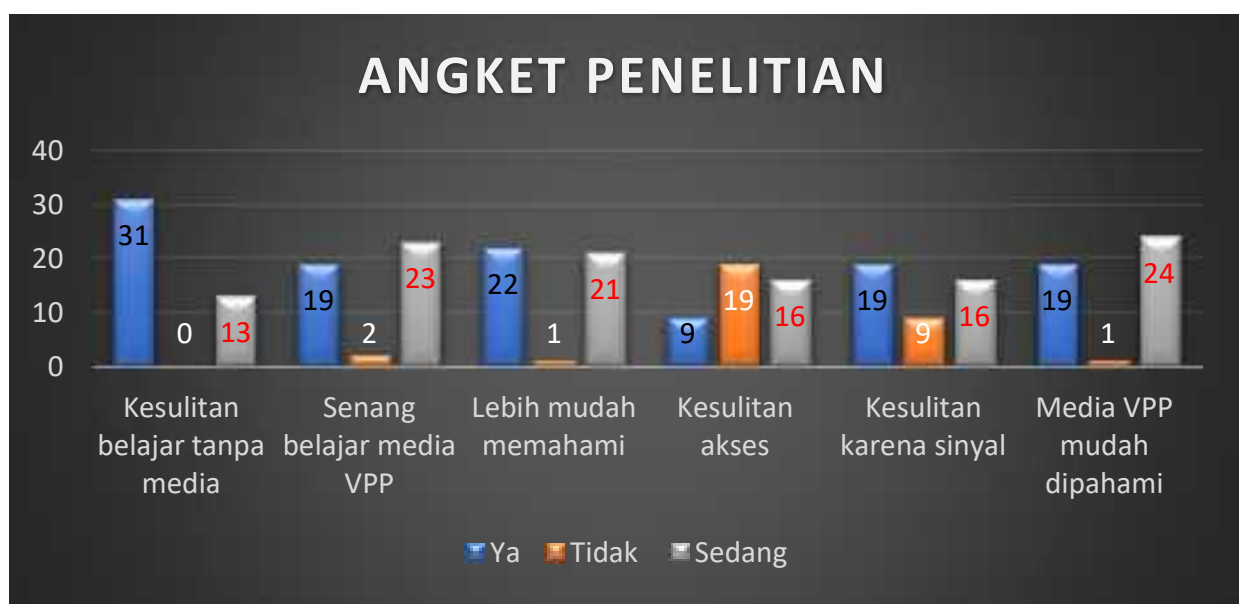

Grafik 1. Diagram Angket Penelitian

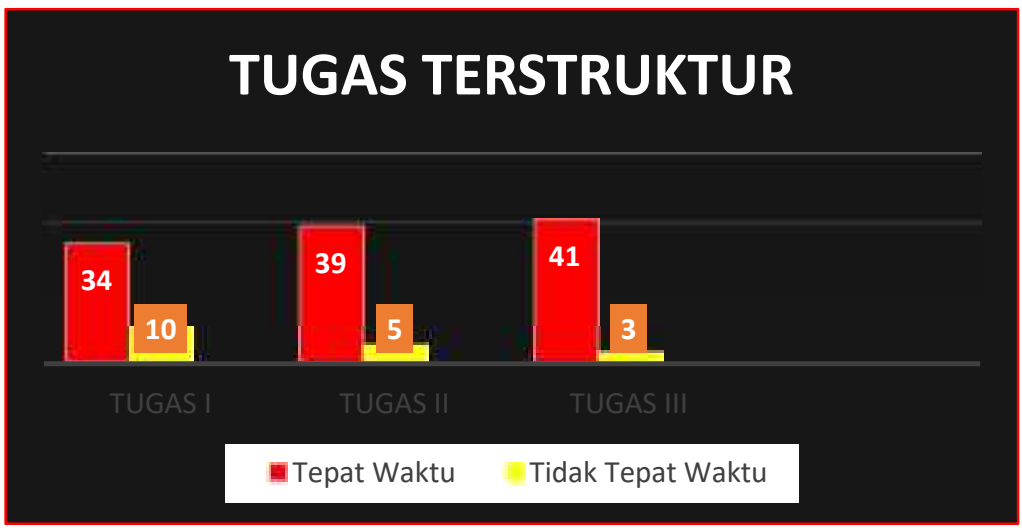

Grafik 2. Diagram Tugas Terstruktur 


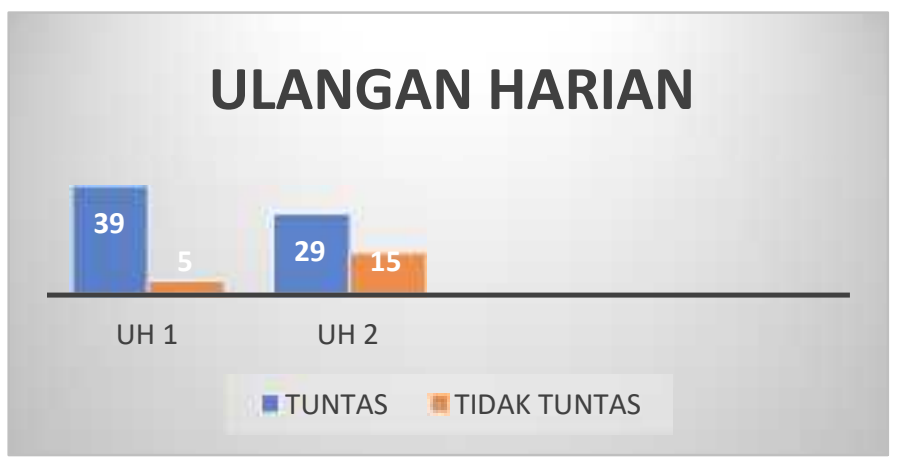

Grafik 3. Diagram Nilai Ulangan Harian

Dari hasil angket penelitian diperoleh data sebagai berikut : (a) Dari pertanyaan "Apakah anda merasa kesulitan ketika belajar Biologi tanpa media pembelajaran?", menunjukan hasil bahwa $70,45 \%$ atau 31siswa merasa kesulitan belajar tanpa menggunakan media pembelajaran, $0 \%$ atau 0 siswa menyatakan tidak dan 29,54\% atau 13 siswa menyatakan sedang, hal ini dapat diartikan hampir seratus persen siswa berharap setiap pembelajaran menggunakan media pembelajaran untuk mempermudah belajar dan meningkatkan pemahaman siswa terhadap materi pembelajaran yang disampaikan pendidik pada saat pembelajara daring. Sesuai teori Kemp and Dylon, 1985 dimana adanya media pembelajaran akan menyebabkan proses pembelajaran menjadi lebih menarik, interaktif, sikap positif siswa dapat ditingkatkan sedangkan menurut Rudi Susilana media berfungsi memperjelas pesan yang disampaikan pendidik sehingga pesan yang disampaikan tidak terlalu verbalitis. (b) Pertanyaan kedua dimana menanyakan apakah ada rasa senang setelah pembelajaran dengan media vidio powerpoint, diperoleh data 19 siswa atau 43,18\% merasa senang dengan pembelajaran vidio powerpoint, 2 siswa atau 4,54\% menyatakan tidak dan 23 siswa atau 52,27\% menyatakan sedang, dari data menunjukkan bahwa siswa lebih senang apabila pembelajaran menggunakan media, dengan munculnya rasa senang dalam proses pembelajaran akan memunculkan motivasi pada siswa sehinga timbul rasa penasaran terhadap materi pembelajaran dan akan muncul semangat untuk belajar lebih baik. Sesuai dengan teori yang dikemukaan oleh Rudi Susilana bahwa media pembelajaran dapat mengoptimaalkan gairah belajar siswa, juga adanya interaksi lebih langsung antara murid dengan sumber belajar. (c) Pertanyaan ketiga dimana siswa yang menyatakan lebih mudah belajar dengan adanya media video powerpoint 50\% (22 siswa) menyatakan ya, 2,27\% (1 siswa) menyatakan tidak, dan 47,72\% (21 siswa) menyatakan sedang, hal ini menyangatkan bahwa siswa menyukai pembelajaran dengan menggunakan media video powerpoint. Dengan kemudahan belajar sangat membantu siswa dalam memahami setiap point essensial materi yang harus dipahami. Dengan demikian tingkat pemahaman siswa terhadap materi pembelajaran semakin tinggi, hal ini sangat mendukung kemampuan siswa untuk lebih meningkatkan daya pikir analisanya. Media video powerpoint dapat membuktikan siswa mendapat pengalaman yang tidak terduga dikarenakan siswa dapat melihat langsung materi pembelajaran/sumber belajar (Andi Prastowo, 302). (d) Pertanyaan keempat apakah siswa kesulitan dalam mengakses pembelajaran saat menggunakan media video 
powerpoint, dari data diperoleh bahwa 20,45\% (9 siswa) menyatakan kesulitan, $43,18 \%$ (19 siswa) tidak dan yang menyatakan sedang 36,36\% (16 siswa) dimana dapat diartikan yang sedangpun kadang merasakan kesulitan mengupload media pembelajaran, sehingga lebih dari 50\% siswa kesulitan mengakses materi pembelajaran. Adanya kendala ini dapat memacu siswa untuk berlatih mencari solusi dan berusaha keras untuk dapat mengakses materi pembelajaran, dengan demikian akan menumbuhkan jiwa tidak mudah putus asa dan bekerja keras dalam menghadapi setiap permasalahan, sesuai dengan materi Dr. Marzuki, M.Ag (2012,) yaitu tentang karakter ketangguhan merupakan sikap tidak kenal putus asa dan karakter kerja keras menunjukkan perilaku yang bersungguh-sungguh dalam menghadapi setiap permasalahan. (e) Pada pertanyaan kelima dimana kesulitan yang siswa hadapi pada saat mengupload materi pembelajaran disebabkan dari sinyal internet yang kurang kuat, dapat dilihat pada data bahwa 43,18\% (19 siswa) menyatakan ya, 20,45\% (9 siswa) menyatakan tidak, 36,36\% (16 siswa) sedang. Dari data menunjukkan bahawa kesulitan upload media disebabkan karena sinyal internet yang lemah, Pengaruh kekuatan sinyal disebabkan factor geografis tempat tinggal siswa dan jauh dari sumber koneksi internet. Hasil penelitian ini sesuai dengan penelitian Dindin Jamaludin, Tete Ratnasari, Heri Gunawan, Epa Paujiah yang menyatakan bahwa pelayanan standart internet adalah kalangsungan konektifitas dari internet. Dengan hasil penelitian hambatan yang dihadapi adalah jaringan internet yang tidak stabil 23\% dan kuota terbatas $21 \%$ menjadi dua aspek besar yang menghambat pembelajaran daring. (f) Pernyataan soal keenam yaitu "Apabila semua kendala dalam pembelajaran menggunakan media video powerpoint dihilangkan, apakah media itu dapat menjadi salah satu media yang mudah untuk dipahami ?" dimana data ini menyangatkan bahwa media video powerpoint merupakan salah satu jenis media yang mudah untuk dipahami apabila semua kendala eksternal terkurangi, hal ini dapat dibuktikan pada data: $43,18 \%$ (19 siswa) menyatakan ya, 2,27\% (1 siswa) menyatakan tidak, 54,52\% (24 siswa) menyatakan sedang. Berdasar data tersebut media pembelajaran video powerpoint merupakan salah satu alternative media pembelajaran yang dapat menunjang pemahaman siswa terhadap materi yang disampaikan pendidik. Hasil penelitian ini sesuai dengan penelitian yang dilakukan oleh Tri Suwano HandokoNoviyanto, Nengsih Juaningsih, dan Eny S. Rosyidatun (2015) yang menyatakan bahwa penggunaan media vidio animasi sistema pernapasan manusia dapat meningkatkan hasil belajar Biologi dan Desi Kristian Lumban Gaol dan Makmur Sirait (2014) yang menyatakan bahwa ada perbedaan hasil belajar siswa dengan menggunakan media power point.

\section{Nilai Tugas Terstruktur}

Dari tugas terstruktur diperoleh data bahwa siswa yang mengumpulkan tugas tidak tepat waktu mengalami penurunan persentase dari $22,72 \%$ (10 siswa) tugas pertama, menjadi 11,36\% (5 siswa) pada tugas kedua, dan hanya 6,81\% (3 siswa) pada pemberian tugas ketiga. Hal ini menunjukkan bahwa motivasi siswa untuk mengerjakan tugas dari pendidik yaitu meringkas, mengerjakan soal dan mengumpulkan tugas tepat waktu semakin tinggi. Adanya media pembelajaran akan memotivasi siswa untuk lebih tertarik belajar sehingga mendorong siswa melakukan 
apa yang ditugaskan terkait dengan materi dimedia tersebut. Sesuai dengan manfaat media pembelajaran menurut Rudi Susilana, adanya media pembelajaran dapat meningkatkan motivasi belajar dan memungkinkan anak belajar mandiri.

\section{Hasil Evaluasi Belajar Siswa}

Berdasar data ulangan harian siswa, dapat diketahui bahwa hasil ulangan harian pertama dengan batas ketuntasan minimal materi pertumbuhan dan perkembangan tumbuhan 77 diperoleh data 88,67\% (39 siswa) tuntas dan yang tidak tuntas adalah $21,37 \%$ (5 siswa). Pada ulangan harian kedua dengan kriteria ketuntasan minimal materi metabolisme 70 siswa yang tuntas adalah 29 siswa $(65,90 \%)$ sedangkan yang tidak tuntas 15 siswa (34,09\%). Dari data diperoleh bahwa ada penurunan ketuntasan jumlah siswa pada ulangan harian kedua $29,55 \%$, dimana pada ulangan harian pertama $95,45 \%$ tuntas dan ulangan harian kedua 65,90\%. Hal ini disebabkan karena materi pembelajaran pada ulangan harian pertama yaitu pertumbuhan dan perkembangan tumbuhan lebih mudah dibandingkan materi pembelajaran ke dua yaitu metabolisme. Sesuai dengan ketentuan penilaian Direktorat Pembinaan SMA Ditjen Pendidikan Dasar dan Menengah (2017) yang menggunakan acuan kriteria, proses penilaian bukan untuk membandingkan capaian siswa dengan siswa yang lain namun digunakan untuk membandingkan penguasaan kompetensi yang ditetapkan. Sehingga dari data dapat diketahui bahwa media pembelajaran Video Powerpoin efektif digunakan dalam proses pembelajaran dimasa pandemi Covid-19.

\section{Hasil Diskusi,}

Diskusi tentang media powerpoint melalui WhatsApp Group diperoleh data: dimana siswa merasa senang dengan pembelajaran menggunakan Video Powerpoint karena merasa lebih paham terhadap materi pembelajaran yang diterimanya, tidak membosankan, dan lebih efektif untuk belajar karena bisa dilakukan kapan dan dimanapun, sesuai teori Kemp and Dylon, 1985 yang menyatakan proses pembelajaran dapat berlangsung kapanpun dan dimanapun, walaupun ada kendala dari beberapa siswa terkait dengan memori HP cepat penuh, louding lambat tetapi hal ini bukan kendala yang menyebabkan siswa tdak mau mengikuti pembelajaran.

\section{KESIMPULAN DAN SARAN}

Berdasarkan pembahasan hasil penelitian, dapat disimpulkan bahwa: media pembelajaran Vidio Powerpoint dapat meningkatkan hasil belajar Biologi pada siswa kelas XII IPA-1 MAN 2 Banjarnegara di masa pandemi covid-19. Dari hasil penelitian ini peneliti berharap pemanfaatan media pembelajaran Video Powerpoint dapat menjadi alternative media pembelajaran pada saat pembelajaran dalam jaringan maupun pembelajaran di luar jaringan khususnya dilingkungan MAN 2 Banjarnegara dan umumnya dilingkungan pendidikan dengan penambahan kualitas dan kuantitas sesuai kemampuan berinovasi dari para penddik. 


\section{DAFTAR PUSTAKA}

Departemen Pendidikan Nasional. 2007. Model-model Pembelajaran Matematikan dan Ilmu Pengetahuan alam. Jakarta, Dirjen Dikdasmen dan Direktorat Pendidikan Luar Biasa. (3)

Jamaluddin, Dindin. Ratnasih, Teti. Gunawan, Heri. Paujiah, Epa. 2020. Pembelajaran Daring Masa Pandemi Covid-19 pada Calon Guru Hambatan, Solusi dan Proyeksi. LP2M. (1)

Kementerian Pendidikan dan Kebudayaan, 2017. Panduan Penilaian oleh Pendidik dan Satuan Pendidikan Sekolah Menengah Atas. Jakarta, Direktorat Pembinaan Sekolah Menengah Atas dan Direktorat Jenderal Pendidikan Dasar dan Menengah. (4-8, 13, 24, 30-31)

Kompulab, tim. 2010. Buku pintar Microsoft office 2010. Yogyakarta, Citra Media. (98)

Kristian, Desi. Gaol, Lumban dan Sirait, Makmur (2014). Pengaruh Model Pembelajaran Inquiry Training menggunakan Media Power Point Terhadap Hasil Belajar Siswa. Jurnal Inpafi 2 (Inovasi Pembelajaran Fisika 2). (36)

Marzuki. 2012. Pendidikan Karakter dan Pengintegrasiannya dalam Pembelajaran. STAIN. (5-6)

Prastowo, Andi. 2012. Panduan kreatif membuat bahan ajar inovatif. Yogjakarta, Diva Press. (2012, 300-302)

Prastowo, Andi. 2011. Memahami Metode-Metode Penelitian. Yogjakarta, Ar-Ruzz Media. (234-235)

Priyatno, duwi. 2010. Microsoft office 2010. Jakarta, Kanaya Press. (108)

Susilana, Rudi. 2008. Media Pembelajaran. Bandung. Wacana Prima. (1-2, 5-9)

Suwano, Tri. Noviyanto, Handoko. Juaningsih, Nengsih dan Rosyidatun, Eny S. 2015. Penggunaan Media Vidio Animasi Sistem Pernapasan Manusia untuk Meningkatkan Hasil Belajar Biologi. Jurnal Research Artikel, EDUSAINS. (6) 